\title{
Defesa Profissional, a FEBRASG0 e a Nova Tabela de Honorários
}

A Comissão de Defesa Profissional da Federação Brasileira das Sociedades de Ginecologia e Obstetrícia (FEBRASGO) está trabalhando, junto à Associação Médica Brasileira (AMB) e as outras Sociedades de Especialidades, para estabelecer um nova tabela de honorários profissionais a ser utilizada no pagamento dos atendimentos médicos.

Esta caminhada começou há algum tempo, com a minuciosa e cuidadosa análise das Tabelas da AMB realizada pelo colega Fernando Ferreira Bernd, que documentou a evolução histórica e apontou suas principais distorções. A partir destas constatações, algumas equiparações a procedimentos semelhantes de outras especialidades já foram conseguidas. Mas muito ainda há que se caminhar. A Comissão de Defesa Profissional da FEBRASGO está trabalhando, com suas congêneres, no estabelecimento de parâmetros, também para procedimentos ainda não reconhecidos e remunerados, que resultarão nos novos patamares a serem apregoados pela Tabela de Honorários Profissionais da AMB, que deverá ser referendada pelo Conselho Federal de Medicina.

Entretanto, este não pode ser apenas trabalho de uns poucos. Precisamos do maior número de colegas unidos em torno deste ideal e, em cada encontro médico, programar discussões onde todos devem e podem se manifestar. Esta é a forma de aumentar a consciência da importância de nossas lutas. Da somatória de idéias e de ações, sairemos mais fortalecidos e os resultados a serem alcançados serão, certamente, melhores.

A Diretoria 